\title{
Heavy Metal Concentrations in Agricultural Farms in Homa Hills Homa Bay County, Kenya
}

\author{
Teresa Akenga ${ }^{1}$, Vincent Sudoi ${ }^{2}$, Walter Machuka ${ }^{3}$, Emmy Kerich $^{4}$ \\ ${ }^{1}$ Vice Chancellor, University Of Eldoret, P.O. BOX 1125, Eldoret, Kenya \\ ${ }^{2,4}$ School of Environmental Science, University Of Eldoret, P.O. BOX 1125,Eldoret, Kenya \\ ${ }^{3}$ University Of Eldoret,Vice Chancellor's Office, P.O.BOX 1125, Eldoret, Kenya
}

\begin{abstract}
Intensified agricultural activities in Kenya over the past few years has led to an increased and persistent use of fertilizers, pesticides, manure, use of machinery in order to increase yield for economic development and achieve the goals of vision 2030 . Large quantities of agrochemicals are regularly added to soils in intensive farming systems to provide adequate nutrients for plant growth. The compounds used to supply these elements contain trace amounts of heavy metals (e.g., Cd and Pb) as impurities, which, after continued fertilizer application may significantly increase their content in the soil. There is need to study impact of intensive use of use of agrochemicals in the farms. Therefore, this study set out to determine the concentrations of the different heavy metals in the soil from agricultural farms of Homa Hills, Homa Bay County. The soil samples were obtained from two agro-ecological zones LM ${ }^{3}$ (Lower Midland3) and $\mathrm{LM}^{4}$ (Lower Midland 4) zone, around the areas of intense maize farming. Six farms in each zone were randomly selected to obtain soil samples. Sampling was done twice; for the dry and wet seasons. Different samples were also collected at two different sampling depths $(0-10 \mathrm{~cm}$ and $11-20 \mathrm{~cm})$ for each sampling point. The concentrations of selected heavy metals for each sample were determined using Inductive couple plasma. Data was presented using tables and figures. T-test was used to compare the variation of heavy metal concentration in the different agro-ecological zones and the different sampling depths. The results obtained showed that the mean concentration of $\mathrm{Pb}, \mathrm{Cd}, \mathrm{Co}, \mathrm{Zn}$ and $\mathrm{Cu}$ ranged between 17.7-31.7 ppm, 7.3-8.3 ppm, 2.5-5.0 ppm, 4.5-30.5 ppm, 10.7-13.3 ppm respectively in $\mathrm{LM}^{3}$ at the depth of $(0-10 \mathrm{~cm}$ and $11-20 \mathrm{~cm})$. In $\mathrm{LM}^{4}$ the mean concentration of Pb, $\mathrm{Cd}$, Co, $\mathrm{Zn}$ and $\mathrm{Cu}$ ranged between 17.75-35.5 ppm, 7.08-8 ppm, 4.9-5.3 ppm, 4.25-17.16 ppm, 12.41-19.25 ppm respectively at the depth of (0-10cm and 11-20cm. The concentrations of $\mathrm{Zn}, \mathrm{Cd}$, and $\mathrm{Pb}$ in soil sample exceeded WHO limits. The 10-20 cm depth had higher concentrations as compared to 0-10 cm sampling depth this could be due to leaching of heavy metals to the lower strata. Finally, the concentrations were higher during the wet season as compared to the dry season. From the findings, farmers are from this area are advise to avoid using chemicals that introduce such elements to the soil.
\end{abstract}

Keywords: Heavy Metals, Agricultural Activities, Agro-ecological zones, Agro-chemicals

\section{Introduction}

Heavy metal contamination is a major concern for ecosystem in general. Industrial sources of heavy metals include smelting, mining, usage of sewage sludge and fertilizers are different sources of contamination (Filgueiras et al., 2002). Mining, phosphate fertilization, lime application, utilization of biosolids, compost manures, sludge, pesticides and through atmospheric depositions are sources for heavy metals contamination of the soil (Raven et al., 1998).

Heavy metal is comprises elements such as metalloids, transition metals, actinides, and lanthanides. Fu \& Wang (2011) defined heavy metals based on their high atomic weights and relative toxicity. It can also be also be defined as those having a specific density of more than $5 \mathrm{~g} / \mathrm{cm} 3$ (Suciu et al., 2008) and (Jarup, 2003). This include metal such lead, cadmium, copper, zinc, chromium and mercury which are major environmental pollutants (Nagajyoti et al., 2010).

Prolonged exposure to heavy metals such as cadmium, copper, lead, nickel and zinc can cause deleterious health effects in humans (Dummee et al., 2012). Long-term exposure Cadmium causes kidney disease, lung damage, and fragile bones (Mebrahtu and Zerabruk, 2011) and (Yeung and Hsu, 2005). Lead can causes high rates of miscarriage, still births, infertility, permanent damage to the central nervous system, brain, kidneys, cancer and even causes death among others (Momodu \& Anyakora, 2010; Araki et al, 2000). Long-term consumption of excess zinc may also result in decreased iron stores (Hughes and Samman, 2006). High doses of copper cause anaemia, liver damage, kidney dysfunction, stomach and intestinal irritation, neurological complications, hypertension and liver and kidney dysfunctions, lung cancer, pneumonia, heart problems and thyroid damage (Kim et al., 2006) and (Lenntech, 2011). Acute exposure to cobalt could cause reproductive and developmental effects (Kim et al., 2006).

Among these anthropogenic activities, agricultural activities have been found to be contributing the greatest percentage in the environmental heavy metals pollution in Kenya (Omwoma et al., 2010; Nyairo et al, 2015). Kenya's economy primarily depends on agriculture where over a large percent of the population live in rural areas and derive their livelihoods mainly from these agricultural activities. Herbicides, pesticides and inorganic fertilizers contain different levels of heavy metals and thus, their use in an endeavor to achieve and sustain high crop yields contributes greatly to heavy metal contamination in the soils, surface water as well as ground water sources. A study done by Mungai et al., (2016) on the occurrences and toxicological risk assessment of eight heavy metals in agricultural soils from Kenya found out the mean values of eight heavy metals were close to the toxicity threshold limit of USEPA standard values of agricultural soils, indicating potential

Volume 5 Issue 10, October 2016 


\section{International Journal of Science and Research (IJSR) \\ ISSN (Online): 2319-7064 \\ Index Copernicus Value (2013): 6.14 | Impact Factor (2015): 6.391}

toxicological risk to the food chain. He further stated that the intensification of human agricultural activities, the growing industrialization, and the rapid urbanization largely influenced the concentration levels of heavy metals in Kenya, Eastern Africa. Moreover Heavy metals are known to accumulate in the plants then passed to the humans through the food chain. Prolonged consumption of unsafe concentrations of heavy metals through foodstuffs may lead to the accumulation of heavy metals in the humans causing disruption of numerous biochemical processes (Njagi, 2013).

Therefore, this study set out to determine the concentrations of the different heavy metals in the agricultural farms of Homa Bay County. The determination of levels of these heavy metals in soils was crucial for sensitizing the general population on the importance of environmental conservation. The study intends to inform the authorities in environment management on the level of heavy metal pollution in the county hence providing a reference for mitigation efforts. Information obtained from this study can be used by the community and other development agents to find alternative farming practices that ensure environmental sustainability.

\section{Methodology}

The study was conducted in Homa Hills, Homa Bay County (HBC). HBC is an administrative county in the Nyanza Province of Kenya. Its capital town is Homa Bay. It consists of six administrative sub- counties namely: Ndhiwa, Rachuonyo North, Mbita, Rachuonyo South, Suba, and Homa Bay itself. The county borders the Siaya County to the North, Kisumu County to the North-East, Kisii County to the South-East and Migori County to the South and Republic of Uganda to the West (Osumba et al., 2011).

Purposive sampling was utilized to select two agroecological zones around the areas of intense farming. In Karachuonyo constituency, Rachuonyo North Sub-County $\left(0^{\circ} 30^{\prime} 0^{\prime \prime} \mathrm{S}, 34^{\circ} 43^{\prime} 0^{\prime \prime} \mathrm{E}\right)$ two zones were selected, these are Kanam B location, It falls under $\mathrm{LM}^{3}$ (Lower Midland 3) agro-ecological zone, where sorghum growing is pre dorminant and Kokoth Katang location, that falls under $\mathrm{LM}^{4}$
(Lower Midland 4) zone, where farming is extensively practiced. Two sub-locations in the locations were randomly selected as well; including Kanyango and Rabuor sublocations in Kanam B Location and Kokoth B and Koredo Sub-Locations in Kokoth Katang Location.

Six farms in each zone were selected to obtain soil samples. Sampling was done twice; for the dry season (February March) before planting and the long rainy season (April July) after planting. Individual samples were collected from three locations in each farm, in a transect, representing locations that are uniformly distributed across the representative portion of the farm. These included two samples at the periphery of the farm and one sample in the middle. A transect sampling pattern was used for field sampling. To ensure that a uniform volume of soil is taken through the full depth of each sampling, increment samples were collected using soil augers, that were kept clean and rust free. Plastic spades were be used to collect soil samples from two depths; $0-10 \mathrm{~cm}$ and $11-20 \mathrm{~cm}$ to coincide with the planting depth of maize and stored in labeled polythene bags. The two depths were chosen in order to assess the effect of depth on the heavy metals and also to assess the persistency of the heavy metals. The samples were transported to Kenya Agricultural Research Institute (KARI) laboratories where analysis was done.

In the laboratory, the concentration of $\mathrm{Zn}, \mathrm{Pb}, \mathrm{Cd}$ and $\mathrm{Cu}$ for each sample were ascertained using Inductive couple plasma-Mass spectrometer using the standard procedure stipulated by (Melaku at al., 2005). Data was presented using tables and figures. T- test was used to compare the variation of heavy metal concentration in the different agro-ecological zones and the different sampling depths.

\section{Results and Discussion}

\section{Heavy Metals Concentrations in the Soil Samples}

The concentrations of the heavy metals in the sampling zones are shown below in figure 1 and 2 below:

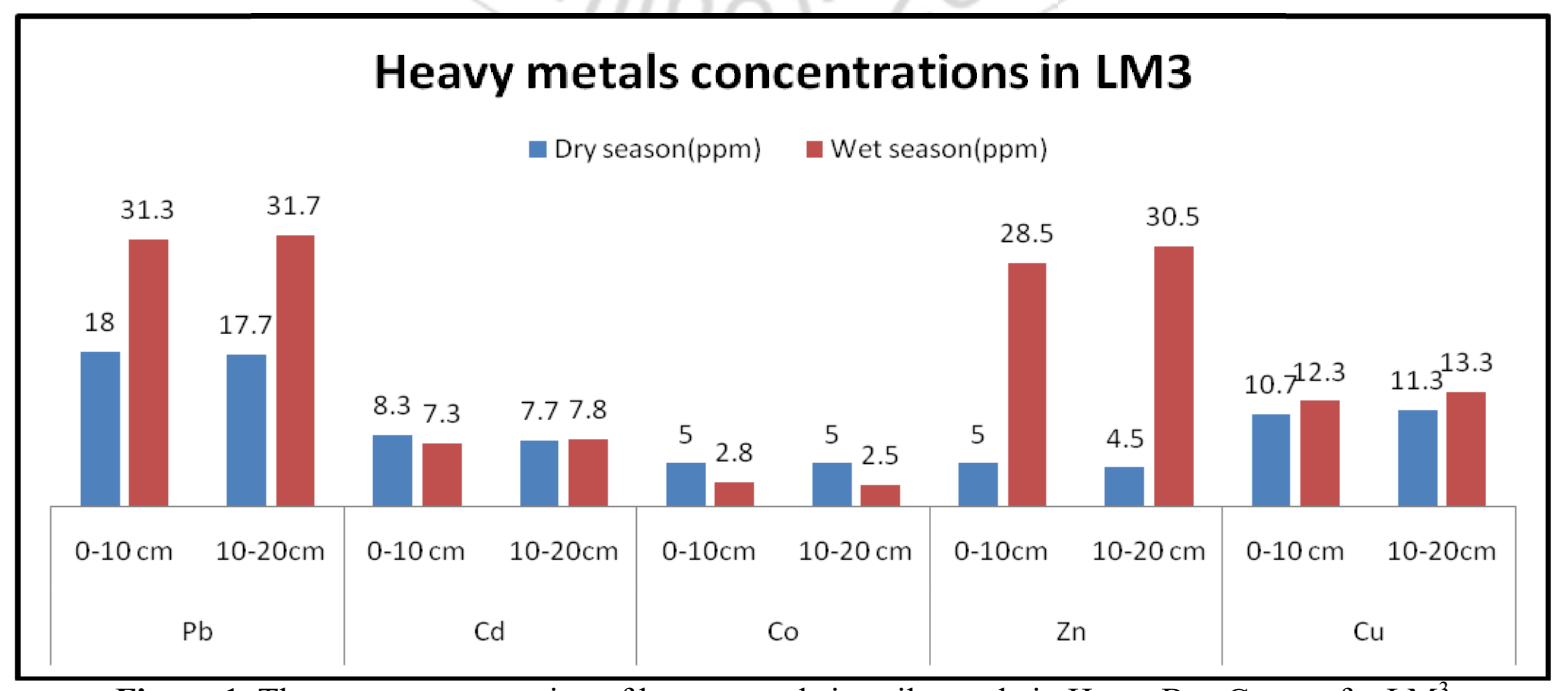

Figure 1: The mean concentration of heavy metals in soil sample in Homa Bay County for LM ${ }^{3}$

The results obtained showed that the mean concentration of $\mathrm{Pb}, \mathrm{Cd}, \mathrm{Co}, \mathrm{Zn}$ and $\mathrm{Cu}$ in $\mathrm{LM}^{3}$ ranged between 17.7-31.7 ppm, 7.3-8.3 ppm, 2.5-5.0 ppm, 4.5-30.5 ppm, 10.7-13.3 ppm respectively.

Volume 5 Issue 10, October 2016 www.ijsr.net 


\section{Heavy metals concentration in LM4}

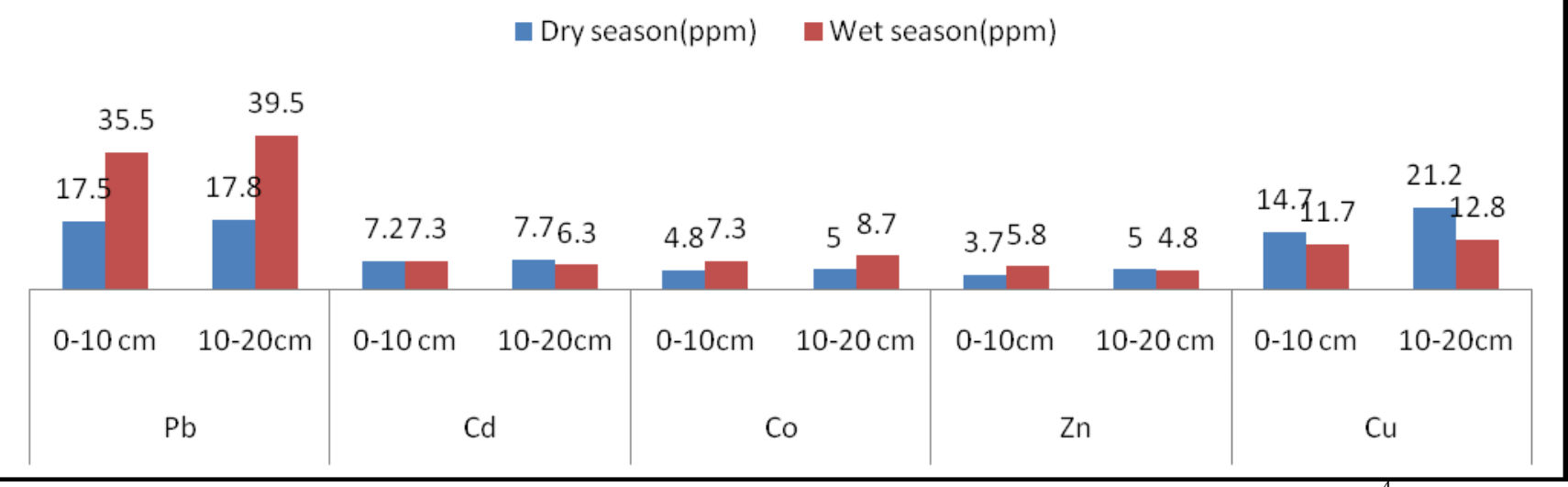

Figure 2: The mean concentration of heavy metals in soil sample in Homa Bay County for $\mathrm{LM}^{4}$

The results obtained showed that the mean concentration of $\mathrm{Pb}, \mathrm{Cd}, \mathrm{Co}, \mathrm{Zn}$ and $\mathrm{Cu}$ ranged between17.75-35.5 ppm, 7.08-8 ppm, 4.9-5.3 ppm, 4.25-17.16 ppm, 12.41-19.25 ppm respectively.

Therefore, the highest concentration of selected heavy metal in $\mathrm{LM}^{4}$ at the depth of $10-20 \mathrm{~cm}$ was $\mathrm{Pb}(35.5) \mathrm{ppm}$ while the lowest was $\mathrm{Zn}$ (4.25) ppm (Figure 1). Few of the heavy The results indicate that the highest mean concentration in the two agro-ecological zone during the dry season was $\mathrm{Cu}$ (21.2 ppm) at the depth of $11-20 \mathrm{~cm}$ in $\mathrm{LM}_{4}$ followed by $\mathrm{Pb}$ with a concentration of $(18.0 \mathrm{ppm})$ and the minimum value being $\mathrm{Zn}(3.7 \mathrm{ppm})$ at the depth of $0-10 \mathrm{~cm}$ in $\mathrm{LM}^{4}$. This finding collaborate with the findings of Romic and Romic, (2003) who asses heavy metals distribution in agricultural top soils in urban area and Wong et al., (2002) who studied heavy metals in agricultural soils of the Pearl River Delta, South China.

During the wet season $\mathrm{Pb}$ had the highest mean concentration of (39.5 ppm) in $\mathrm{LM}^{4}$ at the depth of 11-20 $\mathrm{cm}$. While the lowest concentration during the wet season was Co $(2.5 \mathrm{ppm})$ at the depth of $11-20 \mathrm{~cm}$. This study collaborate with the study done by Ngure, (2013) who found that during the wet season in Kahoya Eldoret the highest metal was $\mathrm{Pb}$. The average concentrations of $\mathrm{Cd}$ in soil sample exceeded WHO standards of $3 \mathrm{ppm}$ (Adelekan and Abegunde, 2011). The acceptable toxic levels in soils for purposes of agriculture are: $\mathrm{Cu}, 60 \mathrm{ppm}$; $\mathrm{Pb}, 100$ ppm; $\mathrm{Zn}$, $70 \mathrm{ppm}$; Co, $35 \mathrm{ppm}$;. The findings were in line with those of Bortey-Sam (2015) who assessed the concentrations of heavy metals and metalloid in soils from agricultural soils around Tarkwa area in Ghana and found that the concentrations of $\mathrm{Cd}, \mathrm{Cu}$ and $\mathrm{Co}$ had exceeded the set standards.

The high level of the lead in the soils may be due to the volcanic activities in the area and also due to use of agrochemicals. The $\mathrm{Pb}$ concentrations recorded from this study were generally higher than the $\mathrm{Pb}$ concentrations reported by Salano (2014) who assessed heavy metals pollutions in soil and water in Samburu County. Cadmium concentration reported from the region exceeded the recommended concentration in the soils of $3 \mathrm{ppm}$ (Adelekan and Abegunde, 2011). The levels of $\mathrm{Cd}$ were in line with concentration levels reported by (Mungai et al., 2016). This may have been due to the intensive application of phosphatic and nitrogen fertilizers such as Di-Ammonium Phosphate,
Metal sample concentration in $\mathrm{LM}^{4}$ agro-ecological zone, these include $\mathrm{Cd}, \mathrm{Pb}$ and zinc exceeded the WHO standard 3ppm, 100ppm and 70ppm in soil (Ezeh and Chukwu, 2011). Calcium Ammonium Nitrogen and Nitrogen Phosphate potassium fertilizers application which adds $\mathrm{Cd}$ and other toxic elements to the soil, including mercury, lead and fluorine (Onder et al., 2007; Raven et al., 1998).

\section{Comparison of the Variation of Concentrations between the two Sampling Depths}

To determine whether there existed significant differences in the concentration of heavy metals in the two sampling depths, a t-test was conducted. The results are presented below:

Table 1: $t$ - test results comparing the two sampling depths in HB County for dry season

\begin{tabular}{|c|c|c|c|c|}
\hline & $\mathrm{t}$ & $\mathrm{Df}$ & Significance (2-tailed) & Mean Difference \\
\hline $\mathrm{Pb}$ & 0 & 22 & 1 & 0 \\
\hline $\mathrm{Cd}$ & 0.69 & 22 & 0.497 & 0.333 \\
\hline $\mathrm{Co}$ & 1 & 22 & 0.328 & 0.083 \\
\hline $\mathrm{Zn}$ & 1.24 & 22 & 0.228 & 0.417 \\
\hline $\mathrm{Cu}$ & 1.1 & 22 & 0.283 & 6.8333 \\
\hline
\end{tabular}

According to the t-test results above, the $\mathrm{p}$ values of $\mathrm{Pb}, \mathrm{Cd}$, $\mathrm{Co}, \mathrm{Zn}$ and $\mathrm{Cu}$ were $1.000,0.497,0.328,0.228$ and 0.283 respectively. All these values were above the 0.05 significance level indicating that the concentration of heavy metals for the two sampling depths $(0-10 \mathrm{~cm}$ and $11-20$ $\mathrm{cm}$ ) for season 1 was not significant at $95 \%$ confidence level. This is attributed to the fact that most of the heavy metals have high leeching capacity and thus percolate to lower layers of the soil strata over tile once in the soils. In addition, most of the heavy metals are highly persistent in the soil and thus significant concentrations will be found long time after use. These findings are in line with those of (Gowd et al, 2010; Rattan et al. (2005) and Tuzen (2003) who did a determination of heavy metals in soil in India, Delhi and Turkey respectively.

To determine whether there existed significant differences in the concentration of heavy metals in the two sampling 


\section{International Journal of Science and Research (IJSR) \\ ISSN (Online): 2319-7064 \\ Index Copernicus Value (2013): 6.14 | Impact Factor (2015): 6.391}

depths, a t-test was conducted. The results are presented below:

Table 2: $t$ - test results comparing the two sampling depths in HB County for wet season

\begin{tabular}{|l|l|l|c|c|}
\hline & $\mathrm{t}$ & $\mathrm{Df}$ & Significance (2-tailed) & Mean Difference \\
\hline $\mathrm{Pb}$ & 0.21 & 22 & 0.836 & 2.167 \\
\hline $\mathrm{Cd}$ & 0.27 & 22 & 0.789 & 0.503 \\
\hline $\mathrm{Co}$ & 0.09 & 22 & 0.929 & 0.25 \\
\hline $\mathrm{Zn}$ & 1.57 & 22 & 0.131 & 12.92 \\
\hline $\mathrm{Cu}$ & 0.05 & 22 & 0.961 & 0.083 \\
\hline
\end{tabular}

According to the t-test results above, the $\mathrm{p}$ values of $\mathrm{Pb}, \mathrm{Cd}$, $\mathrm{Co}, \mathrm{Zn}$ and $\mathrm{Cu}$ were $0.836,0.789,0.929,0.131$ and 0.961 respectively. All these values were above the 0.05 significance level indicating that the concentration of heavy metals for the two sampling depths $(0-10 \mathrm{~cm}$ and $11-20$ $\mathrm{cm}$ ) for season 2 was not significant at $95 \%$ confidence level. This is attributed to the fact that $\mathrm{Pb}, \mathrm{Cd}, \mathrm{Co}, \mathrm{Zn}$ and $\mathrm{Cu}$ have high leeching capacity and thus percolate to lower layers of the soil strata over tile once in the soils. In addition, most of the heavy metals are highly persistent in the soil and thus significant concentrations will be found long time after use. These findings are in line with those of Pandey and Pandey (2003), Peris et al. (2007) and Turer et al. (2001) who assessed heavy metal contamination in soils in India, Europe and Ohio, USA respectively.

Comparison of the Variation of Concentrations between the two Sampling Seasons

To determine whether there existed significant differences in the concentration of heavy metals for the two seasons at the depth of $(0-10 \mathrm{~cm})$, a t-test was conducted. The results are presented below:

Table 3: t- test results comparing the dry and wet season in HB County for depth $0-10 \mathrm{~cm}$

\begin{tabular}{|l|l|l|c|c|}
\hline & $\mathrm{t}$ & $\mathrm{Df}$ & Significance (2-tailed) & Mean Difference \\
\hline $\mathrm{Pb}$ & 2.11 & 22 & 0.046 & 17.8333 \\
\hline $\mathrm{Cd}$ & 0.63 & 22 & 0.535 & 0.9167 \\
\hline $\mathrm{Co}$ & 0.23 & 22 & 0.82 & 0.4167 \\
\hline $\mathrm{Zn}$ & 0.14 & 22 & 0.889 & 0.083 \\
\hline $\mathrm{Cu}$ & 0.41 & 22 & 0.686 & 0.667 \\
\hline
\end{tabular}

According to the t-test results above, the $\mathrm{p}$ values of $\mathrm{Pb}, \mathrm{Cd}$, $\mathrm{Co}, \mathrm{Zn}$ and $\mathrm{Cu}$ were $0.046,0.535,0.820,0.889$ and 0.686 respectively. All these values were above the 0.05 significance level except for $\mathrm{Pb}$ indicating that the difference in concentration of heavy metals for the two seasons was not significant at $95 \%$ confidence level. These results are attributed to the fact that some farmers utilize the land in the first season only. In the second season, only few farmers recultivate their land. This thus implies that the concentration of the different heavy metals in different areas isn't affected significantly. These findings are in line with those of Nabulo et al. (2008), Nicholson et al. (2003), Micó et al.,2006) and Atafar et al. (2010) who assessed concentrations of heavy metals in agricultural fields in Western Kenya, South Wales , Mediterranean and in Arab Emirates respectively. However, the $\mathrm{Pb} \mathrm{p}$-value was below the 0.05 significance level implying that the difference in concentration of $\mathrm{Pb}$ in the sampling points for the two seasons was significant at $95 \%$ confidence level attributed to persistence of $\mathrm{Pb}$ in some areas. To determine whether there existed significant differences in the concentration of heavy metals for the two seasons at the depth of $(11-20 \mathrm{~cm})$, a t-test was conducted. The results are presented below:

Table 4: t- test results comparing dry and wet in HB for 11$20 \mathrm{~cm}$ depth

\begin{tabular}{|c|c|c|c|}
\hline & $\mathrm{t}$ & $\begin{array}{c}\text { Significance } \\
\text { (2-tailed) }\end{array}$ & $\begin{array}{c}\text { Mean } \\
\text { Difference }\end{array}$ \\
\hline $\mathrm{Pb}$ & 2.52 & 0.019 & 15.6667 \\
\hline $\mathrm{Cd}$ & 0.07 & 0.945 & 0.0833 \\
\hline $\mathrm{Co}$ & 0.04 & 0.968 & 0.0833 \\
\hline $\mathrm{Zn}$ & 1.51 & 0.145 & 12.417 \\
\hline $\mathrm{Cu}$ & 1.01 & 0.323 & 6.25 \\
\hline
\end{tabular}

According to the t-test results above, the $\mathrm{p}$ values of $\mathrm{Pb}, \mathrm{Cd}$, $\mathrm{Co}, \mathrm{Zn}$ and $\mathrm{Cu}$ were $0.019,0.945,0.968,0.145$ and 0.323 respectively. All these values were above the 0.05 significance level except for $\mathrm{Pb}$ indicating that the difference in concentration of heavy metals for the two seasons was not significant at $95 \%$ confidence level. The $\mathrm{Pb}$ p-value was below the 0.05 significance level implying that the difference in concentration of $\mathrm{pb}$ in the sampling points for the two seasons was significant at $95 \%$ confidence level. These findings are similar to the $0-10 \mathrm{~cm}$ depth above and thus attributable to the same causal factors. The findings are in line with those of Mapanda et al. (2005), Nicholson et al. (2003) and Sharma et al.,. 2007) who assessed concentrations of heavy metals in agricultural fields for two different seasons in Zimbabwe, South Wales and in India respectively.

\section{Comparison of the Variation of Concentrations between the two Ecological Zones}

To determine whether there existed significant differences in the concentration of heavy metals for the two ecological zones (LM3 and LM4), a t-test was conducted. The results are presented below:

Table 5: t- test results comparing LM3 and LM4 ecological zones

\begin{tabular}{|c|c|c|c|}
\hline & $\mathrm{t}$ & $\mathrm{Df}$ & Significance (2-tailed) \\
\hline $\mathrm{Pb}$ & 0.63 & 8 & 0.5430 \\
\hline $\mathrm{Cd}$ & 0.51 & 8 & 0.3170 \\
\hline $\mathrm{Co}$ & 0.72 & 8 & 0.1403 \\
\hline $\mathrm{Zn}$ & 0.62 & 8 & 0.1830 \\
\hline $\mathrm{Cu}$ & 0.58 & 8 & 0.4210 \\
\hline
\end{tabular}

According to the t-test results above, the $\mathrm{p}$ values of $\mathrm{Pb}, \mathrm{Cd}$, $\mathrm{Co}, \mathrm{Zn}$ and $\mathrm{Cu}$ all above the 0.05 significance level indicating that the difference in concentration of heavy metals for the two ecological zones was not significant at $95 \%$ confidence level. This study was in line with the study done by Cheraghi et al., (2012) who investigated the effects of phosphate fertilizer application on the heavy metal content in agricultural soils with different cultivation patterns. The difference in heavy metal concentration in agro-ecological zone was attributed to the fact that both zones practice agricultural practices similarly in terms of fertilizer application, planting and crop management.

\section{Volume 5 Issue 10, October 2016 www.ijsr.net}




\section{International Journal of Science and Research (IJSR) \\ ISSN (Online): 2319-7064}

Index Copernicus Value (2013): 6.14 | Impact Factor (2015): 6.391

\section{Conclusion and Recommendations}

The average concentration of heavy metals varies in agroecological zones, seasons and sampling depth. $\mathrm{Zn}, \mathrm{Cd}$, and $\mathrm{Pb}$ in soil sample exceeded WHO standard indicating contamination of the soil in the study area. The variation of concentration in different zone could have been influenced by rainfall, soil type and soil $\mathrm{pH}$. The different farms had significant differences in heavy metals concentration attributable to the different chemicals (herbicides and pesticides) and fertilizers used in the different sampling sites in Homa Bay which have different concentrations of the individual heavy metals. In addition, the $11-20 \mathrm{~cm}$ depth had higher concentrations as compared to $0-10 \mathrm{~cm}$ sampling depth. This was attributed to the fact that most of the heavy metals have high leaching capacity and thus percolate to lower layers of the soil strata over tile once in the soils. Finally, the concentrations were higher during the wet season as compared to the dry season. These results are attributed to the fact that some farmers utilize the land in the first season only. In the second season, only few farmers re-cultivate their land. This thus implies that the concentration of the different heavy metals in different areas isn't affected significantly. The presence of heavy metals in the farms could be taken up by plants especially maize in turn could move up the food chain and eventually transfer risk to the maize consumers

In an effort to reduce the heavy metal load in these agricultural soils, the study recommends that the farmers should be sensitized on the types and rates of agricultural chemicals they use in their farms. They should also be made aware of the possible risks of use of unsafe agrochemicals in their farms. Also farmers should be advise on alternative use of pesticide and fertilizers such as organic fertilizers and biopesticides. Further research should be done on the risk associated with heavy metal intake through crops

\section{References}

[1] Adelekan, B., Abegunde, K.,. Heavy metals contamination of soil and groundwater at automobile mechanic villages in Ibadan, Nigeria. Int. J. Phys. Sci 2011, 6, 1045-1058,

[2] Araki, S., Sato, H., Yokoyama, K., and Murata, K.. Subclinical neurophysiological effects of lead: a review on peripheral, central, and autonomic nervous system effects in lead workers. American journal of industrial medicine, 2000, 37(2),193-204.

[3] Atafar, Z., Mesdaghinia, A., Nouri, J., Homaee, M., Yunesian, M., Ahmadimoghaddam, M., \&Mahvi, A. H..Effect of fertilizer application on soil heavy metal concentration. Environmental monitoring and assessment, 2010, 160(1-4), 83-89.

[4] Bortey-Sam, N., Nakayama, S. M., Ikenaka, Y., Akoto, O., Baidoo, E., Yohannes, Y. B., ... \& Ishizuka, M. (2015). Human health risks from metals and metalloid via consumption of food animals near gold mines in Tarkwa, Ghana: Estimation of the daily intakes and target hazard quotients (THQs).Ecotoxicology and environmental safety, 111, 160-167.

[5] Cheraghi, M., Lorestani, B., \& Merrikhpour, H. (2012). Investigation of the effects of phosphate fertilizer application on the heavy metal content in agricultural soils with different cultivation patterns. Biological trace element research, 145(1), 87-92.

[6] Dummee, V., Kruatrachue, M., Trinachartvanit, W., Tanhan, P., Pokethitiyook, P., \& Damrongphol, P. (2012).Bioaccumulation of heavy metals in water, sediments, aquatic plant and histopathological effects on the golden apple snail in Beung Boraphet reservoir, Thailand.Ecotoxicology and environmental safety, 86, 204-212.

[7] Filgueiras, A. V., Lavilla, I., and Bendicho, C. (2002). Chemical sequential extraction for metal partitioning in environmental solid samples. Journal of Environmental Monitoring, 4(6), 823-857.

[8] Fu, F., \& Wang, Q. (2011). Removal of heavy metal ions from wastewaters: a review. Journal of environmental management, 92(3), 407-418.

[9] Gowd, S. S., Reddy, M. R. \& Govil, P. K. (2010).Assessment of heavy metal contamination in soils at Jajmau (Kanpur) and Unnao industrial areas of the Ganga Plain, Uttar Pradesh, India.Journal of Hazardous Materials, 174(1), 113-121.

[10] Hughes, S., and Samman, S. (2006). The effect of zinc supplementation in humans on plasma lipids, antioxidant status and thrombogenesis. Journal of the American College of Nutrition, 25(4), 285-291.

[11] Jarup, L. (2003). Hazards of heavy metal contamination. British medical bulletin, 68(1), 167-182.

[12] Kim J. H., Gibb H. J. and Howe P. D. (2006). Cobalt and inorganic cobalt compounds, WHO, International Chemical Assessment Document 69, pp. 1-85.

[13] Lenntech (2012). Chemical Properties of Cobalt, Health Effects of Cobalt and Environmental Effects of cobalt. www. Lenntech.com. Accessed on 3rd July, 2012. pp. 15.

[14] Mapanda, F., Mangwayana, E. N., Nyamangara, J. \& Giller, K. E. (2005). The effect of long-term irrigation using wastewater on heavy metal contents of soils under vegetables in Harare, Zimbabwe. Agriculture, Ecosystems \& Environment, 107(2), 151-165.

[15] Mebrahtu, G., and Zerabruk, S. (2011). Concentration and Health Implication of Heavy Metals in Drinking Water from Urban Areas of Tigray Region, Northern Ethiopia. Momona Ethiopian Journal of Science, 3(1), 105-121.

[16] Melaku, S., Dams, R. \& Moens, L. (2005). Determination of trace elements in agricultural soil samples by inductively coupled plasma-mass spectrometry: microwave acid digestion versus aqua regia extraction. Analytica Chimica Acta, 543(1), 117123.

[17] Micó, C., Recatalá, L., Peris, M., \& Sánchez, J. (2006). Assessing heavy metal sources in agricultural soils of an European Mediterranean area by multivariate analysis. Chemosphere, 65(5), 863-872.

[18] Momodu, M. A., \& Anyakora, C. A. (2010). Heavy metal contamination of ground water: The Surulere case study. Res. J. Environ. Earth Sci, 2(1), 39-43.

[19] Msc, JOAN MURUGI NJAGI. Assessment of Heavy Metal Concentration in the Environment and Perceived Health Risks by the Community around Kadhodeki Dumpsite, Nairobi county. Diss. KENYATTA UNIVERSITY, 2013.

\section{Volume 5 Issue 10, October 2016}




\section{International Journal of Science and Research (IJSR) \\ ISSN (Online): 2319-7064 \\ Index Copernicus Value (2013): 6.14 | Impact Factor (2015): 6.391}

[20] Mungai, T. M., Owino, A. A., Makokha, V. A., Gao, Y., Yan, X., \& Wang, J. (2016). Occurrences and toxicological risk assessment of eight heavy metals in agricultural soils from Kenya, Eastern Africa. Environmental Science and Pollution Research, $1-9$.

[21] Nabulo, G., Origa, H. O., Nasinyama, G. W., \& Cole, D. (2008).Assessment of $\mathrm{Zn}, \mathrm{Cu}, \mathrm{Pb}$ and $\mathrm{Ni}$ contamination in wetland soils and plants in the Lake Victoria basin.International Journal of Environmental Science \& Technology, 5(1), 65-74.

[22] Nagajyoti, P., Lee, K., and Sreekanth, T. (2010). Heavy metals, occurrence and toxicity for plants: a review. Environmental Chemistry Letters, 8(3), 199-216.

[23] Ngure, V., Sitati, N., Shisia, S., Simiyu, G., Kinuthia, G., \& Kelonye, F. Health implications of heavy metals in soil, scalp hair and selected food crops within Eldoret Municipality, Kenya.

[24] Nicholson, F. A., Smith, S. R., Alloway, B. J., CarltonSmith, C., \& Chambers, B. J. (2003). An inventory of heavy metals inputs to agricultural soils in England and Wales. Science of the total environment, 311(1), 205219.

[25] Nyairo, W. N., Owuor, P. O., \&Kengara, F. O. (2015).Effect of anthropogenic activities on the water quality of Amala and Nyangores tributaries of River Mara in Kenya.Environmental monitoring and assessment, 187(11), 1-12.

[26] Omwoma, S., Lalah, J. O., Ongeri, D. M., \&Wanyonyi, M. B. (2010).Impact of fertilizers on heavy metal loads in surface soils in Nzoia Nucleus Estate sugarcane farms in Western Kenya.Bulletin of environmental contamination and toxicology, 85(6), 602-608.

[27] Onder, S., Dursun, S., Gezgin, S., Demirbas, A., 2007. Determination of heavy metal pollution in grass and soil of city centre green areas (Konya, Turkey). Polish Journal of Environmental Studies 16, 145.

[28] Osumba, J., Muriuki, J., Mwenja, K. 2011. ACCI Project Area Profile (Utumishi Cooperative House, 5th floor Mamlaka Road, Nairobi, Kenya), 5-90.

[29] Pandey, J., \&Pandey, U. (2009).Accumulation of heavy metals in dietary vegetables and cultivated soil horizon in organic farming system in relation to atmospheric deposition in a seasonally dry tropical region of India.Environmental Monitoring and Assessment, 148(14), 61-74.

[30] Peris, M., Micó, C., Recatalá, L., Sánchez, R., \& Sánchez, J. (2007). Heavy metal contents in horticultural crops of a representative area of the European Mediterranean region. Science of the Total Environment, 378(1), 42-48.

[31] Rattan, R. K., Datta, S. P., Chhonkar, P. K., Suribabu, K., \& Singh, A. K. (2005). Long-term impact of irrigation with sewage effluents on heavy metal content in soils, crops and groundwater - a case study. Agriculture, Ecosystems \& Environment, 109(3), 310322.

[32] Raven, K.P., Jain, A., Loeppert, R.H., (1998). Arsenite and arsenate adsorption on ferrihydrite: kinetics, equilibrium, and adsorption envelopes. Environmental Science \& Technology 32, 344-349.
[33] Romic, M., \&Romic, D. (2003).Heavy metals distribution in agricultural top soils in urban area.Environmental Geology, 43(7), 795-805.

[34] Sharma, R. K., Agrawal, M., \& Marshall, F. (2007).Heavy metal contamination of soil and vegetables in suburban areas of Varanasi, India.Ecotoxicology and environmental safety, 66(2), 258-266.

[35] Suciu I., Cosma C., Todica M., Bolboaca S.D. and Jantschi L. (2008). Analysis of Soil Heavy Metal Pollution and Pattern in Central Transylvania. International Journal of Molecular Sciences, 9(4) : 434453

[36] Turer, D., Maynard, J. B., \&Sansalone, J. J. (2001).Heavy metal contamination in soils of urban highways comparison between runoff and soil concentrations at Cincinnati, Ohio.Water, Air, and Soil Pollution, 132(3-4), 293-314.

[37] Tüzen, M. (2003). Determination of heavy metals in soil, mushroom and plant samples by atomic absorption spectrometry. Microchemical Journal, 74(3), 289-297.

[38] Wong, S. C., Li, X. D., Zhang, G., Qi, S. H., \& Min, Y. S. (2002).Heavy metals in agricultural soils of the Pearl River Delta, South China.Environmental Pollution, $119(1), 33-44$.

[39] Yeung, A.T., Hsu, C.-N., 2005. Electrokinetic remediation of cadmium-contaminated clay. Journal of Environmental Engineering, 131, 298-304. 